\title{
Recent Development of Biodiesel Feedstocks and the Applications of Glycerol: A Review
}

\author{
Xiaohu Fan ${ }^{*}$ and Rachel Burton
}

Piedmont Biofuels Industrial, Pittsboro, NC 27312, USA

\begin{abstract}
Biodiesel, as renewable and biological origin alternative diesel fuel, has been receiving a lot of concern throughout the world due to the energy needs and environmental awareness. However, at present, it is not economically feasible to use food-grade vegetable oils to produce biodiesel because of the surge in feedstocks price. Much attention has been devoted to the application of lower-cost feedstocks to produce biodiesel. This paper provided a comprehensive review of biodiesel production from lower-cost non-edible oil sources, such as waste cooking oil (WCO), grease, soapstock, Jatropha oil, and algae. The engine performances of biodiesel produced from these feedstocks were further evaluated. This review also investigated the various applications for the value-added products from glycerol, the byproduct of biodiesel. Moreover, the challenges in terms of different feedstocks and by-product applications were further pointed out.
\end{abstract}

Keywords: Biodiesel, glycerol, grease, jatropha oil, microalgae, waste cooking oil.

\section{INTRODUCTION}

Nowadays, the world energy demand is increasing so rapidly because of increases in industrialization and population that limited reservoirs will soon be depleted at the current rate of consumption. It was known from Oil and Gas Journal (O\&GJ) estimates that at the beginning of 2004, the worldwide reserves were 1.27 trillion barrels of oil and 6,100 trillion cubic feet of natural gas. At today's consumption level of about 85 million barrels per day of oil and 260 billion cubic feet per day of natural gas, the reserves represent 40 years of oil and 64 years of natural gas [1]. Moreover, the increase in pollutants emissions from the use of petroleum fuel will affect human health, such as respiratory system, nervous system and skin diseases etc. Both the energy needs and increased environmental consciousness have stimulated the researching of an alternative fuel. Biodiesel may be the best answer due to its following advantages:

(i) It reduces the country's dependence on imported petroleum.

(ii) It is renewable and contributes less to global warming than petroleum fuel due to its closed carbon cycle. The primary feedstock can grow season after season and most of the carbon in the fuel was originally removed from the air by the plant.

(iii) It provides good engine performance and can be used without engine modification.

(iv) It provides a market for excess production of vegetable oils and animal fats, thus enhancing the rural economies.

*Address correspondence to this author at the Piedmont Biofuels Industrial, 220 Lorax Lane, P.O. Box 661, Pittsboro, NC 27312, USA; Tel: 919-3218260; Fax: 919-321-6769; E-mail: xfan@biofuels.coop (v) It is biodegradable and nontoxic.

(vi) It exhibits lower combustion profile, especially SOx.

Biodiesel can be produced from triglycerides present in naturally occurring fats and oils by transesterification with alcohol, usually methanol, in the presence of catalyst. It is a reversible process and glycerol is as the by-product. The feedstocks used for biodiesel production currently are mainly high quality food-grade vegetable oils, such as soybean oil in United States, rapeseed oil in European, palm oil in Malaysia [2]. However, in order to compete with diesel fuel and survive in the market, lower-cost feedstocks are preferred, including waste cooking oil (WCO), grease, soapstocks [318], since feedstocks costs are about more than $85 \%$ of the total cost of biodiesel production $[19,20]$. The non-edible oils, like Jatropha, can also be used to produce biodiesel [21-26]. In addition, growing interest arises concerning algae-based biodiesel [27].

Meanwhile, due to the increased expansion of biodiesel and the sharp decrease of glycerol prices, many studies were focusing on finding new applications of glycerol as a lowcost feedstock and converting glycerol into value-added chemicals.

In this review article, we examined different biodiesel feedstocks and engine performances of biodiesel produced from these feedstocks. The various applications of valueadded products derived from biodiesel by-product, glycerol, were also summarized.

\section{LOWER-COST FEEDSTOCKS}

Though biodiesel has many advantages compared with petroleum diesel, its high production cost already becomes the primary barrier to its commercialization. Currently, biodiesel unit price is 1.5-3.0 times higher than that of petroleum derived diesel fuel depending on feedstock $[4,20,28]$. Therefore, many studies were focused on the 
utilization of lower-cost feedstocks, such as WCO, grease, soapstock, Jatropha, and algae to produce biodiesel.

\subsection{Biodiesel Production from Waste Cooking Oil}

Waste vegetable oils are generally low in cost. They usually can be collected from large food processing and service facilities. However, due to very high temperature during food frying process, chemical reactions such as hydrolysis, polymerization and oxidation will occur, which can lead to the increase of free fatty acid (FFA) level. Hence, acid catalysis is preferred since it is insensitive to FFA [29]. Zheng et al. [7] studied the reaction kinetics of acidcatalyzed transesterification of waste frying oil. They found that at the methanol/oil molar raito of $250: 1$ at $70{ }^{\circ} \mathrm{C}$ or in the range $74: 1-250: 1$ at $80{ }^{\circ} \mathrm{C}$, the reaction was a pseudo-firstorder. High yield of $99 \pm 1 \%$ could be achieved at both $70{ }^{\circ} \mathrm{C}$ and $80{ }^{\circ} \mathrm{C}$ and a stirring rate of $400 \mathrm{rpm}$, using a feed molar ratio oil:methanol:acid of 1:245:3.8. In contrast, Wang et al. [8] investigated a two-step catalyzed processes for synthesis of biodiesel by using WCO from Chinese restaurants. In the first step, ferric sulfate-catalyzed methanolysis was carried out, while potassium hydroxide catalysis was performed in the second step. The authors made a conclusion that compared with one-step sulfur acid catalysis the two-step catalyzed process provided a more simple and economic method to produce biodiesel from WCO. Moreover, the byproducts of glycerol and soapstock in this process could be easily handled. Similarly, Issariyakul et al. [9] also used the two-step process to transesterify WCO, except that sulfuric acid was selected as acid catalyst and mixtures of methanol and ethanol were used for transesterification in order to use the better solvent property of ethanol and rapid equilibrium using methanol. More than $90 \%$ ester was obtained when two-stage method was used compared with $\sim 50 \%$ ester in single stage alkaline catalyst. The above mentioned two-step process was developed by Canakci et al. [3], in which acid catalyst (usually sulfuric acid) was first chosen to reduce the FFA to less than $1 \%$, then the pretreated feedstock was transesterified under alkaline catalysis. The advantage of this two-step process is that it can increase the reaction rate by using alkaline catalyst and avoid soap formation by applying acid catalyst.

In addition to homogeneous acid and base catalysts, enzyme catalyst was also investigated to transesterify WCO. Chen et al. [10] used immobilized lipase based on Rhizopus orzyae. Their study was focusing on optimization of several parameters, including the molar ratio of methanol to waste oils, biocatalyst load, and adding method, reaction temperature, and water content. The results indicated that methanol/oil ratio of 4/1, immobilized lipase/oil of $30 \mathrm{wt} \%$ and $40{ }^{\circ} \mathrm{C}$ were suitable for waste oils under $1 \mathrm{~atm}$. The irreversible inactivation of the lipase was presumed and a stepwise addition of methanol to reduce inactivation of immobilized lipases was proposed. Under the optimum conditions the yield of methyl esters was around $88-90 \%$.

Heterogeneous catalysts, such as acidic ion-exchange resins, could also be applied on esterification of FFA in WCO. It possessed several advantages over homogeneous catalysts, for example, corrosion prevention [11], easy separation, and high FFA conversions [30]. Özbay et al. [6] examined activities of resins in direct FFA esterification in the temperature range of $50-60{ }^{\circ} \mathrm{C}$ and found all resin catalysts were active. They attributed this to the superiority of physical properties of resins. The differences of catalytic activities between resins were concluded to be related to the size of average pore diameters and magnitude of BET surface area. The experimental results also indicated that FFA conversion increased with increasing reaction temperature and catalyst amount.

\subsection{Biodiesel Production from Grease}

Greases also are one of the less-expensive feedstocks for biodiesel production. Greases mainly contain triglycerides (TG), diglycerides (DG), monoglycerides (MG), and FFA $(8-40 \%)$. A grease containing $8-12 \mathrm{wt} \% \mathrm{FFA}$ is categorized as a yellow grease, and a grease containing $>35 \mathrm{wt} \%$ FFA is categorized as a brown grease [31]. Canakci et al. [3] extended their two-step process to yellow and brown grease, and this process was successfully scaled up to pilot plant [5]. The biodiesel produced from yellow grease was further tested in a four-cylinder turbocharged diesel engine and significant reductions in particulates, $\mathrm{CO}$, and $\mathrm{HC}$ were observed compared with No. 2 diesel [32]. Although the pretreatment step could reduce the FFA content in the greases to $<1 \mathrm{wt} \%$, a large amount of base catalyst was required to neutralize the acid catalyst remaining in the pretreated greases, thus increased the overall biodiesel production cost. As a solution, Ngo et al. [12] developed an efficient procedure for the production of biodiesel from greases, in which a series of diarylammonium catalysts were used that are highly effective in catalyzing the esterification of the FFA present in greases (12-40 wt $\%$ FFA). It was reported that at a catalyst loading of 2-3 mol\%, high conversions of FFA to esters (95-99\%) were achieved by treating the greases with $5-20$ equiv of methanol at $95^{\circ} \mathrm{C}$ for $2 \mathrm{~h}$. The treated greases had a final FFA content of $0.5-1$ $w t \%$. The authors also incorporated these diarylammonium catalysts into insoluble porous polymers via free radicalinitiated polymerization. The polymer-immobilized catalysts were found to be equally effective as their homogeneous counterparts in esterifying FFA to esters. More importantly, the heterogeneous catalysts could be readily removed from the treated greases and reused for esterification reactions upon reactivation with triflic acid.

Other novel approaches were also reported. Cao et al. [13] used a continuous membrane reactor to produce biodiesel from different feedstocks, including yellow and brown grease. The high purity biodiesel produced could meet and exceed the ASTM D 6751 standard.

\subsection{Biodiesel Production from Soapstock}

Soapstock, known as the by-product of the refining of vegetable oils, is another low value feedstock for biodiesel production. Soapstock contains a substantial amount of water, which can be emulsified with the lipid constitutes and is difficult to remove. In addition, the presence of both FFA and acylglycerols makes the transesterification reaction more complicated. Alkaline catalysis cannot be utilized due to the high FFA level [3]. Haas et al. [14] developed a simple, high-efficiency method for synthesis of biodiesel from soapstock. The process involved two steps: the first step, alkaline hydrolysis of all lipid-linked fatty acid ester bonds and the second step, acid-catalyzed esterification of the 
resulting fatty acid sodium salts. In the first step, all glycerides and phosphoglycerides in the soapstock could be completely saponified. After water removal, the resulting FFA sodium salts were rapidly and quantitatively converted into fatty acid methyl ester (FAME) by incubation with methanol and sulfuric acid at $35^{\circ} \mathrm{C}$ and ambient pressure in the second step. The specifications of the FAME produced could meet the current specifications for biodiesel. This developed bench-scale method was further taken to the small pilot scale, producing about $2.5 \mathrm{~L}$ of material per run, according to Haas et al. [33]. All variables examined for the ester product, including flash point, water and sediment, carbon residue, sulfated ash, density, kinematic viscosity, sulfur, cetane number, cloud point, copper corrosion, acid number, free glycerin, and total glycerin were within the provisional biodiesel specifications of the ASTM. Density and iodine values were comparable to those of commercial soy-based biodiesel. The emissions profile was quite similar to that of biodiesel produced from refined soy oil, showing the reductions of total hydrocarbons, particulates and $\mathrm{CO}$, compared with petroleum diesel fuel. However, Haas et al. [34] found that though this method could achieve the efficient production of high-purity biodiesel, substantial amounts of solid sodium sulfate were generated as a byproduct. The cost related to the disposal of this waste material could be high. Therefore, they only used acid catalyzed esterification to produce biodiesel from soapstock. The optimal conditions for the maximum esterification were found to be at $65{ }^{\circ} \mathrm{C}, 26 \mathrm{~h}$, a molar ratio of total FA/methanol/sulfuric acid of 1:1.5:1.5. Further economic analysis by Haas [35] suggested that the production cost of soapstock biodiesel would be approximately US\$ $0.41 / 1$, a $25 \%$ reduction relative to the estimated cost of biodiesel produced from soy oil.

Unlike Haas, Jin et al. [15] developed a three-step process for producing biodiesel from the mixture of oil sediments (OS) and soapstocks (SS), at the same time, phosphatides were obtained. In the first step, the OS-SS mixture was extracted with ethyl ether and the mixture was divided into three phases. Cooled acetone was chosen to extract the organic top phase, including triglycerides and phosphatides. Phosphatides were separated from triglycerides since they were insoluble in the acetone. In the second step, soap phase was acidified with sulfuric acid to yield fatty acid. Then the so called "high acid" acid oil was efficiently converted into methyl esters by acid-catalyzed esterification. The esterification reaction was carried out with 5:1 methanol/oil $(\mathrm{mol} / \mathrm{mol})$ in the presence of $3 \%$ sulfuric acid as an acid catalyst at $85{ }^{\circ} \mathrm{C}$ for $5 \mathrm{~h}$. Biodiesel recovery under these conditions was $92.1 \%$ of theoretical. Alkaline catalyzed transesterification process was performed in the third step to convert the triglycerides into biodiesel and glycerol. The maximum ester yield of $94 \%$ was obtained under the optimal variables: $6 / 1$ methanol/oil (mol/mol), $1 \%$ $\mathrm{NaOH}$ (wt.\%), $65^{\circ} \mathrm{C}$, and $1 \mathrm{~h}$. Five important fuel properties of biodiesel from the OS-SS mixture, including density (at $15^{\circ} \mathrm{C}$ ), kinematic viscosity (at $40{ }^{\circ} \mathrm{C}$ ), flash point, calorific value, and acid value, were found to be comparable to those of No. 2 diesel fuel and conforming to both the American and German standards for biodiesel.

Recently, Wang et al. [16] pointed out three major disadvantages of the process developed by Haas: 1. High temperature steam are required since conventional acidulation method is taken to recover acid oil from soapstock. 2. Additional process, saponification of the glycerides, is needed to convert them to free fatty acid salts. 3 . The esterification reaction time is too long, leading to low productivity. The authors developed an attractive method to produce biodiesel from soybean soapstock. Separation of extracted acid oil from soapstock was performed with only sulfuric acid solution under the ambient temperature $(25 \pm 2$ $\left.{ }^{\circ} \mathrm{C}\right)$. The maximum acid oil recovery yield of $97 \%$ could be achieved based on the total fatty acids of the soapstock. The acid oil could be directly converted into biodiesel at $95^{\circ} \mathrm{C}$ in a pressurized reactor within 5 hours and the yield of purified biodiesel was $94 \%$ based on the total fatty acids of the soapstock. The optimal esterification conditions were determined to be a weight ratio of 1:1.5:0.1 of acid oil/methanol/sulfuric acid. After distillation, the biodiesel produced by using this method could meet the Biodiesel Specification of Korea.

Besides soybean oil soapstock, other soapstocks are also of interest to be utilized to produce biodiesel, thus increasing the potential supply of this fuel as well. Usta et al. [17] first used hazelnut soapstock/waste sunflower oil mixture to produce biodiesel. The process involved two steps, including acid (sulfuric acid) and base (sodium hydroxide) catalysis. The hazelnut soapstock/waste sunflower oil mixture was first heated to $100^{\circ} \mathrm{C}$ to remove the water. Then, the mixture was left to cool to $35^{\circ} \mathrm{C}$ before two-step catalysis.

In summary, WCO, grease, and soapstock are potential feedstocks for biodiesel production, which can lower the cost of biodiesel since they are inexpensive. However, since all these feedstocks contain high FFA, it will cause soap and water formation when using alkaline catalyst, which could decrease the ester yield and make the separation of ester, glycerol, and wash water more difficult. Acid catalysts can convert FFAs into esters, but the reaction rate is too slow. Moreover, this process requires more alcohol and large reactors and it is corrosive [36]. The two-step process, of which the first step serves as pretreatment, is usually preferred. However, this will increase the additional unit cost. Supercritical transesterification process can be an alternative method due to the following advantage: 1 . Pretreatment step, soap and catalyst removal are not necessary since catalyst is not required [37-40]. 2. The reaction duration is significantly shorter than traditional transesterification reaction [41]. 3. The reaction is not sensitive to both FFA and water [39,42]. However, this method requires high molar ratio of alcohol to feedstock $[37,38,41]$ and high reaction pressure and temperature, which will cause high operating cost.

\subsection{Biodiesel Production from Jatropha Oil}

There is growing interest for biodiesel production from non-edible oil source, like Jatropha curcas L. (JCL). JCL is a plant belonging to Euphorbiaceae family, which is a nonedible oil-bearing plant widespread in arid, semi-arid and tropical regions of the world [43]. It has an estimated annual production potential of 200 thousand metric tones in India and it can be grown in waste land [44]. Singh et al. [45] gave detailed information on the use of different components of JCL fruit for energy purposes. It was found that the shell 
could be for combustion, hull/husk for gasification, cake for production of biogas, spent slurry as manure, oil and biodiesel (made from Jatropha oil) for running CI engines. The kernels have about $50 \%$ oil. The oil recovery in mechanical expeller was about $85 \%$, while more than $95 \%$ recovery of oil could be achieved when extracted by solvent method.

JCL has a great potential as biodiesel due to its comparable properties to diesel, such as calorific value and cetane number [46]. Therefore, many researchers showed great concern about using Jatropha oil to produce biodiesel. Azam et al. [2] found FAME of Jatropha curcas were most suitable for use as biodiesel and it met the major specification of biodiesel standards of USA, Germany and European Standard Organization. Sarin et al. [47] made an appropriate blends of Jatropha and palm biodiesel to improve oxidation stability and low temperature property based on the fact that Jatropha biodiesel has good low temperature property and palm biodiesel has good oxidative stability. It was found that antioxidant dosage could be reduced by $80-90 \%$ when palm oil biodiesel is blended with Jatropha biodiesel at about $20-40 \%$. This techno-economic combination could be an optimum mix for Asian Energy Security. Tiwari et al. [21] used response surface methodology to optimize three important reaction variables, including methanol quantity, acid concentration, and reaction time. The optimum combination for reducing the FFA of Jatropha oil from $14 \%$ to less than $1 \%$ was found to be $1.43 \% \mathrm{v} / \mathrm{v}$ sulfuric acid catalyst, $0.28 \mathrm{v} / \mathrm{v}$ methanol-to-oil ration and $88 \mathrm{~min}$ reaction time at $60{ }^{\circ} \mathrm{C}$ for producing biodiesel. The properties of Jatropha oil biodiesel conformed to the American and European standards. As comparison, Berchmans et al. [22] developed a two-step pretreatment process in which the high FFA $(15 \%)$ of Jatropha curcas seed oil was reduced to less than $1 \%$. In the first step, the reaction was carried out with $0.60 \mathrm{w} / \mathrm{w}$ methanol-to-oil ratio in the presence of $1 \mathrm{wt} \%$ sulfuric acid as an acid catalyst in $1 \mathrm{~h}$ at $50{ }^{\circ} \mathrm{C}$. In the second step, the transesterification reaction was performed using $0.24 \mathrm{w} / \mathrm{w}$ methanol-to-oil ratio and $1.4 \mathrm{wt} \%$ sodium hydroxide as alkaline catalyst to produce biodiesel at $65{ }^{\circ} \mathrm{C}$. The final biodiesel yield of $90 \%$ in $2 \mathrm{~h}$ was reported. As well as experimental study, theoretical studies of reaction mechanism were also conducted regarding to base-catalyzed transesterification of the glycerides of the Jatropha oil [23]. In this study, Semi-empirical AM1 molecular orbital calculations were used to investigate the reaction pathways of base-catalyzed transesterification of glycerides of palmitic, oleic and linoleic acid. The researchers concluded that the reaction mechanism included three steps: Step 1Nucleophilic attack of the alkoxide anion on the carbonyl group of the glyceride to form a tetrahedral intermediate. Step 2-Breaking of the tetrahedral intermediate to form the alkyl ester and the glyceride anion. Step 3-Regeneration of the active catalyst, which may start another catalytic cycle. This study suggested that the Step 2, decomposition of the tetrahedral intermediate, determined the rate of basecatalyzed transesterification of glycerides.

It should be mentioned here that a lot of different approaches were taken when producing biodiesel from Jatropha oil. In additional to conventional methods, preparation of biodiesel from Jatropha oil using ultrasonic energy was investigated [24]. Low frequency ultrasound (33 $\mathrm{kHz}$ ) was applied to transesterify Jatropha oil with methanol in the presence of base catalyst at 6:1 methanol/oil molar ratio. The reaction time (about 15-30 min) was much shorter than conventional mechanic stirring method. This method proved to be efficient and economically functional. Moreover, enzyme catalysts were also utilized for biodiesel production from Jatropha oil. Shah et al. [25] evaluated the lipase from P. cepacia for conversion of Jatropha oil into biodiesel. The best yield of $98 \%$ was obtained by using Pseudomonas cepacia lipase immobilized on celite at $50{ }^{\circ} \mathrm{C}$ in the presence of $4-5 \%(\mathrm{w} / \mathrm{w})$ water in $8 \mathrm{~h}$. With respect to economic factor, this enzyme-based process could use commercial grade ethanol instead of expensive grade ethanol. Moreover, the biocatalyst could be used four times without loss of any activity. Rathore et al. [26] used Novozym-435 lipase to synthesize biodiesel from Jatropha oil in presence of supercritical carbon dioxide. The optimum conditions were found to be $8 \mathrm{~h}, 45^{\circ} \mathrm{C}, 5: 1$ molar ratio of alcohol to oil and an enzyme loading of $30 \%$ based on the weight of oil. However, conversions of only $60-70 \%$ were obtained even after $8 \mathrm{~h}$. The authors attributed this to the fact that the enzymatic reaction encountered both substrate and product inhibition. In contrast, when synthesis of biodiesel in supercritical alcohols, very high conversions $(>80 \%)$ were obtained within 10 min and nearly complete conversions were obtained within $40 \mathrm{~min}$. Despite of expected high operating cost due to high temperature and pressure associated with supercritical alcohol, it was still considered to be economically feasible since the reaction time was very short [39]. Furthermore, the absence of pre-treatment step, soap removal, and catalyst removal can significantly reduce the capital cost of a biodiesel plant.

Though received a booming interest due to its general characteristics and potential, it was recommended by some researchers that better data are urgently needed to guide investment since uncertainty do exist, based on the fact that Jatropha curcas is still a wild plant which exhibits a lot of variability in yield, oil content and oil quality [48]. These researchers conducted an extensive study on Jatropha biodiesel fueling sustainability, including three inseparable dimensions: environmental, economic and social. They emphasized the situation-specific interactions between different sustainability dimensions and the consideration of the political and ethical side of bioenergy production. Achten et al. [49] pointed out in their review article that based on the available information it is still difficult to conclude if JCL biodiesel will meet the two essential minimum requirements for bio-fuels to be a more sustainable alternative for fossil fuels (i.e. (i) produced from renewable raw material and (ii) their use has a lower negative environmental impact).

\subsection{Biodiesel Production from Microalgae}

Replacing all the transport fuel consumed in the United States with biodiesel will require 0.53 billion $\mathrm{m}^{3}$ of biodiesel annually at the current rate of consumption [50]. Therefore, oil crops, waste cooking oil, soapstock, Jatropha oil cannot satisfy this demand. However, this situation may be changed dramatically when microalgae are used to produce biodiesel. Microalgae are grown in such a well-designed system in which better access to water, $\mathrm{CO}_{2}$, and nutrients is provided by the aquatic environment. This contributes to its higher 
average photosynthetic efficiency compared with land crops. It deserves to mention here that any biofuel is ultimately a means of collecting solar energy and storing it in an energy dense chemical [1]. Feedstocks possessing greater net efficiency for utilizing solar energy through photosynthesis will be highly desired. Moreover, microalgae grow extremely rapidly and commonly double their biomass within $34 \mathrm{~h}$. During exponential growth, this time can be shortened as low as $3.5 \mathrm{~h}$. It is estimated that the biomass productivity of microalgae could be 50 times more than that of switchgrass, which is the fastest growing terrestrial plant [51]. The oil content in microalgae is rich, commonly 20 $50 \%$ [50]. Some microalgae exceeds $80 \%$ oil content by weight of dry biomass [52,53].

Currently the practical methods of large-scale production of microalgae are open ponds, most commonly raceway ponds [54], and tubular photobioreactors [55,56]. The United States Department of Energy sponsored extensive studies concerning production of microalgae biomass for making biodiesel [57]. Although raceways are low-cost, the biomass productivity was lower than photobioreactors. The main disadvantage of open systems is that they lose water by evaporation at a rate similar to land crops and are also susceptible to contamination by unwanted species, being open to the atmosphere [58]. Unlike open raceways, photobioreactors save water, energy and chemicals. It can provide a controlled environment that can be tailored to the specific demands of highly productive microalgae to attain a consistly good annual yield of oil [50]. Therefore, the choice of cultivation systems is the key point which can significantly affect the efficiency and cost-effectiveness of microalgal biofuel production process [59]. This topic was discussed extensively by many researchers [50,60-64].

Microalgae possess the following attractive characteristics that are ideal for biodiesel production [65]:

1. Costs associated with the harvesting and transportation of microalgae are relatively low, compared with those of other biomass materials such as conventional crops.

2. Microalgae can be chemically treated.

3. Algae can grow under conditions that are unsuitable for conventional crops.

4. Microalgae are capable of fixing $\mathrm{CO}_{2}$ in the atmosphere, thereby assisting the reduction of atmosphere $\mathrm{CO}_{2}$ levels, which are now considered a global problem.

Many projects were funded for microalgae biodiesel production, such as the one at the University of Utah. A number of other projects to manufacture biodiesel from algae are under way around the world. For example, International Power Hazelwood (Morwell, VIC, Australia) and the Victor Smorgon Group (VSG; Melbourne, VIC, Australia) are running a six-month pilot test of a process from GreenFuel Technologies Corp. (Cambridge, MA) that uses microalgae in a photobioreactor to sequester carbon dioxide from furnace gases (IB 11/24/06). VSG will convert the oil from the algal biomass into biodiesel at its existing large plant for manufacturing biodiesel from canola oil. In another project, Solazyme Inc. (Menlo Park, CA) is working to genetically engineer Dunaliella, a green eukaryotic microalga to improve its performance (IB 7/7/06). It is already used to produce beta-carotene and also can accumulate significant quantities of lipids suitable for making biodiesel [66]. Aresta et al. [27] conducted a research to compare with two different techniques, the thermochemical liquefaction and the supercritical carbon dioxide $\left(\mathrm{sc}-\mathrm{CO}_{2}\right)$ extraction, for the extraction of oil from microalgae to produce biodiesel. It was found that thermochemical liquefaction was more efficient than the sc- $\mathrm{CO}_{2}$ method from the quantitative point of view but decomposition of the fatty acid might occur under the operative conditions. Also, it required temperature around 350 and $395^{\circ} \mathrm{C}$ to obtain the optimal amount of extracted oil.

Despite the seemingly bright future of using microalgae to produce biodiesel, this is still years away from being ready for actual commercial implementation. Vasudevan et al. [1] pointed out in their review paper that the biggest challenge is the capital cost of photobioreactors, which will present a barrier to commercialization. On the other hand, Chisti [50] was optimistic with the improvement level which could be achieved for economical microalgae biodiesel production. The author stated in the review article that through genetic and metabolic engineering, algal biology could be improved for producing lower-cost microalgae biodiesel. Furthermore, by incorporation of biorefinery concept and utilizing the advances in photobioreactor engineering, the production cost could be further reduced.

\section{ENGINE PERFORMANCE OF BIODIESEL}

\subsection{Engine Performance of Biodiesel from Waste Cooking Oil}

The performances of biodiesel obtained from WCO in terms of engine performance and emissions were also studied by many researchers. Çetinkaya et al. [67] investigated the engine performance of biodiesel fuel originated from used cooking oil in a Renault Mégane automobile and four stroke, four cylinder, F9Q732 code and $75 \mathrm{~kW}$ Renault Mégane Diesel engine in winter conditions for $7500 \mathrm{~km}$ road tests in urban and long distance traffic. The results showed that the torque and brake power output obtained during the used cooking oil originated biodiesel application were $3-5 \%$ less than those of No. 2 diesel fuel. The engine exhaust gas temperature at each engine speed of biodiesel was less than that of No. 2 diesel fuel. Higher values of exhaust pressures were found for No. 2 diesel fuel at each engine speed. The injection pressures of both fuels were similar. Based on the experimental results of this study, the authors concluded that used cooking oil originated biodiesel could be recommended as a No. 2 diesel fuel alternative for winter conditions. Lin et al. [68] also used WCO to prepare biodiesel and then conducted a study in which the trace formation from the exhaust tail gas of a diesel engine when operated using the different fuel type, including neat biodiesel, biodiesel/diesel blends, and normal diesel fuels, were compared. Among the collected data, they found that B20 and B50 were the optimum fuel blends. As comparison, Al-Widyan et al. [69] utilized ethyl ester of waste vegetable oils as fuel in diesel engines and initiated a study to investigate its potential to substitute oil-based diesel fuel. The fuels evaluated included $100 \%$ ester, several ester/diesel blends and diesel fuel as the baseline fuel. The 
tests were run on a standard test rig of a single-cylinder, direct-injection diesel engine. The results indicated that the blends burned more efficiently with less specific fuel consumption, resulting in higher thermal efficiency. Moreover, less carbon monoxide $(\mathrm{CO})$ and unburned hydrocarbons (HC) than diesel fuel were produced for the blends. The blends and 100\% ester surpassed the diesel fuel in essentially all aspects of engine performance considered. Overall, 100\% ester and 75:25 ester/diesel gave the best results regarding performance, while as for emissions concerned, the 50:50 blends exhibited the best results. The ester fuel demonstrated a high potential as fuel for diesel engines. Similar trend for emission results were observed by Dorado et al. [70], who characterized exhaust emissions from a diesel engine fueled with transesterified waste olive oil and found lower emissions of $\mathrm{CO}$, carbon dioxide $\left(\mathrm{CO}_{2}\right)$, nitrogen oxide (NO), and $\mathrm{SO}_{2}$. The particulate emissions from used cooking oil biodiesel were also evaluated by the researcher [71]. The biodiesel fuels were tested in a DI diesel commercial engine either pure or in $30 \%$ and $70 \% \mathrm{v} / \mathrm{v}$ blends with a reference diesel fuel. A sharp decrease was observed in both smoke and particulate matter emissions as the biodiesel concentration was increased. This was attributed by the authors to the fact that the oxygen content of the biodiesel improved the oxygen availability in rich-zone flames in the combustion chamber. Recently, an environmental approach was used by Nas et al. [72], who presented an overview of energy potential of biodiesel generated from WCO. The authors finally draw a conclusion that biodiesel could reduce nearly all forms of air pollution, especially air toxics and cancer-causing compounds.

\subsection{Engine Performance of Biodiesel from Soapstock}

The effects of the biodiesel addition to the diesel fuel on the performance and emissions of a four cycles, four cylinder, turbocharged indirect injection diesel engine were investigated at both full and partial loads. Experimental results indicated that the hazelnut soapstock/waste sunflower oil methyl ester could be partially substituted for diesel fuel at most operating conditions without any engine modification and preheating of the blends. Keskin et al. [18] used cotton oil soapstock to produce biodiesel. Then the cotton oil soapstock biodiesel was blended with diesel fuel. The blends were tested in a single cylinder direct injection diesel engine. It was reported that high calorific value and cetane number, low sulfur and aromatic content, and similar characteristics were observed for the blends. The power output and torque of engine with blends were decreased by $6.2 \%$ and $5.8 \%$, respectively. Particulate material emission of the engine with blends at maximum torque speed was decreased by $46.6 \%$. It was concluded that blends of cotton oil soapstock biodiesel and diesel fuel could be used as alternative fuels in conventional diesel engines without any major changes.

\subsection{Engine Performance of Biodiesel from Jatropha}

Many researches were conducted aiming at evaluating the performance, emission, and combustion characteristics in a diesel engine for Jatropha oil and Jatropha oil biodiesel [45,73-75]. Haldar et al. [74] found that Jatropha oil gave the best results related to the performance and emissions, such as $\mathrm{CO}, \mathrm{CO}_{2}, \mathrm{HC}$, smoke and particulates, at high loads and $45^{\circ}$ bTDC injection timing when compared with nonedible straight vegetable oils of Putranjiva, Jatropha and Karanja. Kumar et al. [75] used Jatropha oil and methanol in various methods, such as blending, transesterification and dual fuel operation (methanol/Jatropha oil=3:7, v/v) to compare with performance, emission and combustion parameters. Experimental results indicated that Jatropha oil and methyl ester showed higher diffusion combustion compared to standard diesel operation. Jatropha oil could be used as fuel in diesel engines directly and by blending it with methanol. Use of methyl ester of Jatropha oil and dual fuel operation with methanol induction could give better performance and reduced smoke emissions than the blend. Similar trend was obtained from other researchers [45], who found that biodiesel from Jatropha oil offered higher brake thermal efficiency than blended de-waxed de-gummed Jatropha oil or even diesel. It could be blended with diesel in any proportion or could be used as pure biodiesel successfully in CI engine without any problem. In spite of above-mentioned advantages related to engine emissions, higher NOx level in the Jatropha based biodiesel exhaust was reported by several researchers $[76,77]$. To solve this, Pradeep et al. [78] effectively employed a low cost technique, hot exhaust gas recirculation (HOT EGR). Compared with COOLED EGR, this method was costeffective and easy to implement. The optimal EGR level was $15 \%$, based on adequate reduction in nitric oxide emissions, minimum possible smoke, $\mathrm{CO}, \mathrm{HC}$ emissions and reasonable brake thermal efficiency.

\section{FROM GLYCEROL TO VALUE-ADDED PRODUCTS}

The cost of biodiesel includes two aspects. One is the raw material (feedstocks) cost. The other is the production cost, of which the recovery of by-product (glycerol) is one of the important parts. Due to the large surplus of glycerol formed as a by-product during the production of biodiesel, new opportunities for the conversion of glycerol into value-added chemicals have emerged in recent years, which will definitely promote biodiesel commercialization and further development.

As a nontoxic, edible, biosustainable and biodegradable compound [79-81], glycerol can be converted into promising commodity chemicals and fuels through chemoselectively catalysis, such as selective oxidation, selective hydrogenolysis, catalytic dehydration, pyrolysis and gasification, selective glycerol transesterification and esterification, selective etherification and carboxylation.

Selective oxidation includes: 1 . oxidation of primary hydroxyl groups, which yields glyceric acid and further tartronic acid; 2. oxidation of the secondary hydroxyl group, which yields the important fine chemical dihydroxyacetone (DHA); and 3. oxidation of all three hydroxyl groups, which yields the highly functionalized molecule mesoxalic acid. Extensive researches concerning selective catalysis of glycerol to produce glyceric acid [82-88], DHA [89-93], and mesoxalic acid were conducted. All the functional derivatives obtained have commercial values. For instance, DHA is the main active ingredient in all sunless tanning skincare preparations and can be as building block of new degradable polymers if in a lower market price situation [94- 
95]. Mesoxalic acid is potentially valuable chelating agents that can be used as intermediate compounds for the synthesis of fine chemicals and novel polymers.

Selective hydrogenolysis of glycerol in the presence of metallic catalysts and hydrogen can produce 1,2-propanediol (1,2-PD), 1,3-propanediol (1,3-PD), or ethylene glycol (EG). $1,2-\mathrm{PD}$ is used for polyester resins, liquid detergents, pharmaceuticals, cosmetics, tobacco humectants, flavors and fragrances, personal care, paints, animal feed, antifreeze, etc. 1,3-PD is used in specialty polyester fibers, films, and coatings. EG is a raw material for synthetic fibers and explosives [96].

Dehydration of glycerol can produce acrolein, which is a versatile intermediate largely employed by the chemical industry for the production of acrylic acid esters, superabsorber polymers, and detergents.

Pyrolysis and gasification of glycerol were also investigated by many researchers to generate $\mathrm{CO}, \mathrm{H}_{2}$, etc. [97-99]. Similar promising is the conversion of glycerol into syngas by steam reforming.

Selective glycerol transesterification and esterification can yield monoglycerides (MG) and polyglycerol esters (PEG). MG can be applied as emulsifiers in food, pharmaceutical, and cosmetic industries [100]. Melero et al . [101] reported the esterification of glycerol with acetic acid to produce glycerine acetates, such as diacetylglycerol (DAG) and triacetylglycerol (TAG), which have been shown to be valuable petrol fuel additives leading to either enhanced cold and viscosity properties when blended with diesel fuel or antiknocking properties when added to gasoline.

Selective etherification of glycerol can yield more valuable fuel additives or solvents with suitable properties. Among these, tert-butyl ethers exhibit potential to be used as diesel fuel additives in gasoline and offer an alternative to oxygenates such as methyl tert-butyl ether (MTBE) and ethyl tert-butyl ether (ETBE). Selective etherification can also convert glycerol into polyglycerol (PG) and PEG, which have been recommended to be used as biodegradable surfactants, lubricants, cosmetics, food additives [102-104].

Carboxylation of glycerol can produce glycerol carbonate. A lot of attentions have been received for this new and interesting material in the chemical industry [105-107].

Inexpensive glycerol carbonate can be utilized as a source of new polymeric materials for the production of polycarbonates and polyurethanes [108].

Glycerol can also be used to prepare dichloropropanol (DCP) [109] and as substrate to produce organic solvent tolerant lipase [110].

To sum up, glycerol can be converted into many valueadded products through catalytic process. However, new challenges appear since the glycerol obtained as a by-product from the biodiesel industry is crude and impure. Zhou et al. [111] stated the following four challenges we need face in their review article: 1. new application and products based for directly using crude glycerol need to be found; 2. costeffective purification process need to be developed to purify raw glycerol from biodiesel processes; 3. a combination of separation of crude glycerol with catalytic conversion; and 4 . direct biocatalytic conversion using crude glycerol should be investigated and developed to make it economically practical.

\section{CONCLUSIONS AND FUTURE SCOPE OF RESEARCH}

Biodiesel serves as a promising renewable substitute for diesel fuel. However, the surge in feedstock price has been the greatest barrier to its commercialization. The objective of this study was to present an overall review of the biodiesel productions from various lower-cost feedstocks and their engine performances. Biodiesel produced from these feedstocks displayed better engine emission profiles that were suitable for use as diesel fuel.

This review also presented various applications for valueadded products from chemoselective catalytic conversion of glycerol by-product, which could enhance economic viability of biodiesel production.

The combination of using lower-cost feedstock with production of value-added co-products may greatly enhance biodiesel industry profitability. However, many challenges still remain.

(i) WCO, grease, and soapstock all contain high level of FFA. Transesterification cannot be applied directly when using alkaline catalyst, which is the commonly accepted method in the industry at present.

(ii) JCL is still a wild plant. Its environmental effect has not been investigated.

(iii) Algae-based biodiesel is gaining increasing importance. However, research in this area is still limited and in early stages.

(iv) Glycerol can be converted into many value-added products through chemoselectively catalytic processes. However, it is difficult to directly use crude glycerol with high levels of impurities.

Based on these challenges, future scope of research should focus on developing novel catalytic processes for biodiesel production, such as heterogeneous catalysis, which can not only be suitable for low quality feedstocks with high FFA, but simplify downstream separation and improve the purity of by-product crude glycerol. As for JCL, More data need to be collected before we conclude that JCL biodiesel meet the requirements of biofuel sustainability. Researchers should also incorporate biorefinery concept, genetic and metabolic engineering knowledge to further study the application of microalgae as biodiesel feedstocks. Positive results will be probably achieved over the next few years if the research efforts will continue at the same rate as today.

\section{ACKNOWLEDGEMENT}

The authors wish to acknowledge Piedmont Biofuels Industrial for financing this review study.

\section{REFERENCES}

[1] Vasudevan, P.T.; Briggs, M. Biodiesel production-current state of the art and challenges. J. Ind. Microbiol. Biotechnol., 2008, 35, 421-430. 
[2] Azam, M.M.; Waris, A.; Nahar, N.M. Prospects and potential of fatty acid methyl esters of some non-traditional seed oils for use as biodiesel in India. Biomass Bioenergy, 2005, 29, 293-302.

[3] Canakci, M.; Gerpen, J.V. Biodiesel production from oils and fats with high free fatty acids. Transact. ASAE, 2001, 44(6), 1429-1436.

[4] Zhang, Y.; Dubé, M.A.; McLean, D.D.; Kates, M. Biodiesel production from waste cooking oil: 1. Process design and technological assessment. Bioresource Technol., 2003, 89, 1-16.

[5] Canakci, M.; Gerpen, J.V. A pilot plant to produce biodiesel from high free fatty acid feedstocks. Trans. ASAE, 2003, 46(4), 945-954.

[6] Özbay, N.; Oktar, N.; Tapan, N.A. Esterification of free fatty acids in waste cooking oils (WCO): Role of ion-exchange resins. Fuel, 2008, 87, 1789-1798.

[7] Zheng, S.; Kates, M.; Dubé, M.A.; McLean, D.D. Acid-catalyzed production of biodiesel from waste frying oil. Biomass Bioenergy, 2006, 30, 267-272.

[8] Wang, Y.; Ou, S.Y.; Liu, P.Z.; Xue, F.; Tang, S. Comparison of two different processes to synthesize biodiesel by waste cooking oil. J. Mol. Catal. A-Chem., 2006, 252, 107-112.

[9] Issariyakul, T.; Kulkarni, M.G.; Dalai, A.K.; Bakhshi, N.N. Production of biodiesel from waste fryer grease using mixed methanol/ethanol system. Fuel Process. Technol., 2007, 88, 429436.

[10] Chen, G.; Ying, M.; Li, W.Z. Enzymatic conversion of waste cooking oils into alternative fuel-Biodiesel. Appl. Biochem. Biotech., 2006, 129-132, 911-921.

[11] Silva, V.M.T.M.; Rodrigues, A.E. Kinetic studies in a batch reactor using ion exchange resin catalysts for oxygenates production: Role of mass transfer mechanisms. Chem. Eng. Sci., 2006, 61, 316-331.

[12] Ngo, H.L.; Zafiropoulos, N.A.; Foglia, T.A.; Samulski, E.T.; Lin, W.B. Efficient two-step synthesis of biodiesel from greases. Energy Fuel, 2008, 22, 626-634.

[13] Cao, P.G.; Dubé, M.A.; Tremblay, A.Y. High-purity fatty acid methyl ester production from canola, soybean, palm, and yellow grease lipids by means of a membrane reactor. Biomass Bioenergy, 2008, 32, 1028-1036.

[14] Haas, M.J.; Bloomer, S.; Scott, K. Simple, high-efficiency synthesis of fatty acid methyl esters from soapstock. J. Am. Oil Chem. Soc., 2000, 77(4), 373-379.

[15] Jin, B.; Zhu, M.; Fan, P.; Yu, L.J. Comprehensive utilization of the mixture of oil sediments and soapstocks for producing FAME and phosphiatides. Fuel Process. Technol., 2008, 89, 77-82.

[16] Wang, Z.M.; Lee, J.S.; Park, J.Y.; Wu, C.Z.; Yuan, Z.H. Novel biodiesel production technology from soybean soapstock. Kor. J. Chem. Eng., 2007, 24(6), 1027-1030.

[17] Usta, N.; Öztürk, E.; Can, Ö.; Conkur, E.S.; Nas, S.; Çon, A.H.; Can, A. Ç.; Topcu, M. Combustion of biodiesel fuel produced from hazelnut soapstock/waste sunflower oil mixture in a diesel engine. Energy Convers. Manage., 2005, 46, 741-755.

[18] Keskin, A.; Gürü, M.; Altiparmak, D; Aydin, K. Using of cotton oil soapstock biodiesel-diesel fuel blends as an alternative diesel fuel. Renewable Energy, 2008, 33, 553-557.

[19] Haas, M.J.; McAloon, A.J.; Yee, W.C.; Foglia, T.A. A process model to estimate biodiesel production costs. Bioresource Technol., 2006, 97, 671-678.

[20] Zhang, Y.; Dubé, M.A.; McLean, D.D.; Kates, M. Biodiesel production from waste cooking oil: 2. Economic assessment and sensitivity analysis. Bioresource Technol., 2003, 90, 229-240.

[21] Tiwari, A.K.; Kumar, A.; Raheman, H. Biodiesel production from jatropha oil (Jatropha curcas) with high free fatty acids: An optimized process. Biomass Bioenergy, 2007, 31, 569-575.

[22] Berchmans, H.J.; Hirata, S. Biodiesel production from crude Jatropha curcas L. seed oil with a high content of free fatty acids. Bioresour. Technol., 2008, 99, 1716-1721.

[23] Tapanes, N.C.O.; Aranda, D.A.G.; Carneiro, J.W.D.M.; Antunes, O.A.C. Transesterification of jatropha curcas oil glycerides: Theoretical and experimental studies of biodiesel reaction. Fuel, 2008, 87, 2286-2295.

[24] Kachhwaha, S.S.; Maji, S.; Faran, M.; Gupta, A.; Ramchandran, J.; Kumar, D. Preparation of biodiesel from jatropha oil using ultrasonic energy. Proceedings of the National Conference on Trends and Advances in Mechanical Engineering, YMCA Institute of Engineering, Faridabad, Haryana, Dec. 9-10, 2006; pp. 1-5.

[25] Shah, S.; Gupta, M.N. Lipase catalyzed preparation of biodiesel from Jatropha oil in a solvent free system. Process. Biochem., 2007, 42, 409-414.
[26] Rathore, V.; Madras, G. Synthesis of biodiesel from edible and non-edible oils in supercritical alcohols and enzymatic synthesis in supercritical carbon dioxide. Fuel, 2007, 86, 2650-2659.

[27] Aresta, M.; Dibenedetto, A.; Carone, M.; Colonna, T.; Fragale, C. Production of biodiesel from microalgae by supercritical $\mathrm{CO}_{2}$ extraction and thermochemical liquefaction. Environ. Chem. Lett., 2005, 3, 136-139.

[28] Demirbas, A. Importance of biodiesel as transportation fuel. Energy Policy, 2007, 35, 4661-4670.

[29] Freedman, B.; Pryde, E.H.; Mounts, T.L. Variables affecting the yields of fatty esters from transesterified vegetable oils. J. Am. Oil Chem. Soc., 1984, 61(10), 1638-1643.

[30] Lotero, E.; Liu, Y.J.; Lopez, D.E.; Suwannakarn, K.; Bruce, D.A.; Goodwin, J.G. Synthesis of biodiesel via acid catalysis. Ind. Eng. Chem. Res., 2005, 44, 5353-5363.

[31] Kulkarni, M.G.; Dalai, A.K. Waste cooking oil-An economical source for biodiesel: A review. Ind. Eng. Chem. Res., 2006, 45, 2901-2913.

[32] Canakci, M.; Van Gerpen, J.H. Comparison of engine performance and emissions for petroleum diesel fuel, yellow grease biodiesel, and soybean oil biodiesel. Trans. ASAE, 2003, 46(4), 937-944.

[33] Haas, M.J.; Scott, K.M.; Alleman, T.L.; McCormick, R.L. Engine performance of biodiesel fuel prepared from soybean soapstock: A high quality renewable fuel produced from a waste feedstock. Energy Fuel, 2001, 15, 1207-1212.

[34] Haas, M.J.; Michalski, P.J.; Runyon, S.; Nunez, A.; Scott, K.M. Production of FAME from acid oil, a by-product of vegetable oil refining. J. Am. Oil Chem. Soc., 2003, 80(1), 97-102.

[35] Haas, M.J. Improving the economics of biodiesel production through the use of low value lipids as feedstocks: vegetable oil soapstock. Fuel Process. Technol., 2005, 86, 1087-1096.

[36] Canakci, M.; Sanli, H. Biodiesel production from various feedstocks and their effects on the fuel properties. J. Ind. Microbiol. Biotechnol., 2008, 35, 431-441.

[37] He, H.Y.; Wang, T.; Zhu, S.L. Continuous production of biodiesel fuel from vegetable oil using supercritical methanol process. Fuel, 2007, 86, 442-447.

[38] Demirbaş, A. Biodiesel from vegetable oils via transesterification in supercritical methanol. Energy Convers. Manage., 2002, 43:2349-2356.

[39] Van Kasteren, J.M.N.; Nisworo, A.P. A process model to estimate the cost of industrial scale biodiesel production from waste cooking oil by supercritical transesterification. Resour. Conserv. Recy. 2007, 50, 442-458.

[40] Han, H.W.; Cao, W.L.; Zhang, J.C. Preparation of biodiesel from soybean oil using supercritical methanol and $\mathrm{CO}_{2}$ as co-solvent Process. Biochem., 2005, 40, 3148-3151.

[41] Saka, S.; Kusdiana, D. Biodiesel fuel from rapeseed oil as prepared in supercritical methanol. Fuel, 2001, 80, 225-231.

[42] Kusdiana, D.; Saka, S. Effects of water on biodiesel fuel production by supercritical methanol treatment. Bioresource Technol., 2004, 91, 289-295.

[43] Chhetri, A.B.; Tango, M.S.; Budge, S.M.; Watts, K.C.; Islam, M.R. Non-edible plant oils as new sources for biodiesel production. Int J. Mol. Sci., 2008, 9, 169-180.

[44] Srivastava, A.; Prasad, R. Triglycerides-based diesel fuels. Renewable Sust. Energy Rev., 2000, 4, 111-133.

[45] Singh, R.N.; Vyas, D.K.; Srivastava, N.S.L.; Narra, M. SPRERI experience on holistic approach to utilize all parts of Jatropha curcas fruit for energy. Renewable Energy, 2008, 33, 1868-1873.

[46] Sirisomboon, P.; Kitchaiya, P.; Pholpho, T.; Mahuttanyavanitch, W. Physical and mechanical properties of Jatropha curcas L. fruits, nuts and kernels. Biosyst. Eng., 2007, 97, 201-207.

[47] Sarin, R.; Sharma, M.; Sinharay, S.; Malhotra, R.K. Jatropha-palm biodiesel blends: An optimum mix for Asia. Fuel, 2007, 86, 1365 1371.

[48] Achten, W.M.J.; Mathijs, E.; Verchot, L.; Singh, V.P.; Aerts, R.; Muys, B. Jatropha biodiesel fueling sustainability. Biofuels Bioprod. Bioref., 2007, 1, 283-291.

[49] Achten, W.M.J.; Verchot, L.; Franken, Y.J.; Mathijs, E.; Singh, V.P.; Aerts, R.; Muys, B. Jatropha bio-diesel production and use. Biomass Bioenergy, 2008, 32, 1063-1084.

[50] Chisti, Y. Biodiesel from microalgae. Biotechnol. Adv., 2007, 25 294-306.

[51] Demirbaş, A. Oily products from mosses and algae via pyrolysis. Energy Sources Part A, 2006, 28, 933-940. 
[52] Metting, F.B. Biodiversity and application of microalgae. J. Ind. Microbiol., 1996, 17, 477-489.

[53] Spolaore, P.; Joannis-Cassan, C.; Duran, E.; Isambert, A. Commercial applications of microalgae. J. Biosci. Bioeng., 2006, 101(2), 87-96.

[54] Terry, K.L.; Raymond, L.P. System design for the autotrophic production of microalgae. Enzyme Microb. Technol., 1985, 7, 474487.

[55] Grima, E.M.; Fernández, F.G.A.; Camacho, F.G.; Chisti, Y. Photobioreactors: Light regime, mass transfer, and scaleup. $J$. Biotechnol., 1999, 70, 231-247.

[56] Mirón, A.S.; Gómez, A.C.; Camacho, F.G.; Grima, E.M.; Chisti, Y. Comparative evaluation of compact photobioreactors for largescale monoculture of microalgae. J. Biotechnol., 1999, 70, 249270.

[57] Sheehan, J.; Dunahay, T.; Benemann, J.; Roessler, P. A look back at the U.S. Department of Energy's Aquatic Species Programbiodiesel from algae. National Renewable Energy Laboratory, Golden, Colorado, 1998.

[58] Schenk, P.M.; Thomas-Hall, S.R.; Stephens, E.; Marx, U.C.; Mussgnug, J.H.; Posten, C.; Kruse, O.; Hankamer, B. Second generation biofuels: High-efficiency microalgae for biodiesel production. Bioenergy Res., 2008, 1, 20-43.

[59] Li, Y.Q.; Horsman, M.; Wu, N.; Lan, C.Q.; Dubois-Calero, N. Biofuels from microalgae. Biotechnol. Prog., 2008, 24, 815-820.

[60] Lee, Y.K. Microalgal mass culture systems and methods: Their limitation and potential. J. Appl. Phycol., 2001, 13, 307-315.

[61] Pulz, O. Photobioreactors: production systems for phototrophic microorganisms. Appl. Microbiol. Biotechnol., 2001, 57, 287-293.

[62] Carvalho, A.P.; Meireles, L.A.; Malcata, F.X. Microalgal reactors: A review of enclosed system designs and performances. Biotechnol. Prog., 2006, 22, 1490-1506.

[63] Chaumont, D. Biotechnology of algal biomass production: A review of systems for outdoor mass culture. J. Appl. Phycol., 1993, 5(6), 593-604.

[64] Janssen, M.; Tramper, J.; Mur, L.R.; Wijffels, R.H. Enclosed outdoor photobioreactors: light regime, photosynthetic efficiency, scale-up, and future prospects. Biotechnol. Bioengy, 2003, 81(2), 193-210.

[65] Miyamoto, K. Renewable biological systems for alternative sustainable energy production (FAO agricultural services bulletin128). Osaka, Japan, 1997.

[66] Seefeldt, L.C. Utah group plans to make biodiesel from algae. Ind Bioprocess. 2007

[67] Cetinkaya, M.; Ulusoy, Y.; Tekìn, Y.; Karaosmanoğlu, F. Engine and winter road test performances of used cooking oil originated biodiesel. Energy Convers. Manage., 2005, 46, 1279-1291.

[68] Lin, Y.F.; Wu, Y.P.G.; Chang, C.T. Combustion characteristics of waste-oil produced biodiesel/diesel fuel blends. Fuel, 2007, 86, 1772-1780.

[69] Al-Widyan, M.I.; Tashtoush, G.; Abu-Qudais, M. Utilization of ethyl estero $\mathrm{f}$ waste vegetable oils as fuel in diesel engines. Fuel Process. Technol., 2002, 76, 91-103.

[70] Dorado, M.P.; Ballesteros, E.; Arnal, J.M.; Gómez, J.; López, F.J. Exhaust emissions from a diesel engine fueled with transesterified waste olive oil. Fuel, 2003, 82, 1311-135.

[71] Lapuerta, M.; Rodríguez-Fernández, J.; Agudelo, J.R. Diesel particulate emissions from used cooking oil biodiesel. Bioresource Technol., 2008, 99, 731-740.

[72] Nas, B.; Berktay, A. Energy potential of biodiesel generated from waste cooking oil: An environmental approach. Energy Sources, Part B, 2007, 2, 63-71.

[73] Sivaprakasam, S.; Saravanan, C.G. Optimization of the transesterification process for biodiesel production and use of biodiesel in a compression ignition engine. Energy Fuel, 2007, 21, 2998-3003.

[74] Haldar, S.K.; Ghosh, B.B.; Nag, A. Studies on the comparison of performance and emission characteristics of a diesel engine using three degummed non-edible vegetable oils. Biomass Bioenergy, 2009, 33, 1013-1018.

[75] Kumar, M.S.; Ramesh, A.; Nagalingam, B. An experimental comparison of methods to use methanol and Jatropha oil in a compression ignition engine. Biomass Bioenergy, 2003, 25, 309318.

[76] Sharma, R.P. Bio-diesel and E-diesel in transportation-an OEM perspective. In: Processings of XVIII National Conference on IC Engines, Trivandrum, December. 2003; pp. 539-550.
[77] Chairman. Committee on development of bio-fuel. Report of committee on development of bio-fuels. Planning Commission, Government of India, April 2003.

[78] Pradeep, V.; Sharma, R.P. Use of hot EGR for NOx control in a compression ignition engine fuelled with bio-diesel from Jatropha oil. Renewable Energy, 2007, 32, 1136-1154.

[79] Wang, Z.X.; ZhuGe, J.; Fang, H.Y.; Prior, B.A. Glycerol production by microbial fermentation: A review. Biotechnol. Adv., 2001, 19, 201-223.

[80] Chiu, C.W.; Goff, M.J.; Suppes, G.J. Distribution of methanol and catalysts between biodiesel and glycerin phases. AICHE J., 2005 , 51(4), 1274-1278

[81] Bournay, L.; Casanave, D.; Delfort, B.; Hillion, G.; Chodorge, J.A New heterogeneous process for biodiesel production: A way to improve the quality and the value of the crude glycerin produced by biodiesel plants. Catal. Today, 2005, 106, 190-192.

[82] Abbadi, A.; Bekkum, H.V. Highly selective oxidation of aldonic acids to 2-keto-aldonic acids over Pt-Bi and Pt-Pb catalysts. Appl. Catal. A-Gen, 1995, 124, 409-417.

[83] Kimura, H. Oxidation assisted new reaction of glycerol. Polym Adv. Technol., 2001, 12, 697-710.

[84] Kimura, H. Polyketomalonate by catalytic oxidation of glycerol over a CeBiPt catalyst. II. J. Polym. Sci. Part A: Polym Chem, 1996, 34, 3607-3614.

[85] Kimura, H. Polyketomalonates by catalytic oxidation of glycerol. I. J. Polym. Sci. Part A: Polym. Chem., 1996, 34, 3595-3605.

[86] Kimura, H. Poly (ketomalonate) by catalytic oxidation of glycerol (4) anionic polymerization. J. Polym. Sci. Part A: Polym. Chem., 1998, 36, 195-205.

[87] Besson, M.; Gallezot, P. Selective oxidation of alcohols and aldehydes on metal catalysts. Catal. Today, 2000, 57, 127-141.

[88] Carrettin, S.; McMorn, P.; Johnston, P.; Griffin, K.; Kiely, C.J.; Hutchings, G.J. Oxidation of glycerol using supported Pt, Pd and Au catalysts. Phys. Chem. Phys. 2003, 5, 1329-1336.

[89] Garcia, R.; Besson, M.; Gallezot, P. Chemoselective catalytic oxidation of glycerol with air on platinum metals. Appl. Catal. AGen, 1995, 127, 165-176.

[90] Gallezot, P. Selective oxidation with air on metal catalysts. Catal. Today, 1997, 37, 405-418.

[91] Fordham, P.; Besson, M.; Gallezot, P. Selective catalytic oxidation of glyceric acid to tartronic and hydroxypyruvic acids. Appl. Catal. A-Gen, 1995, 133, L179-184.

[92] Ciriminna, R.; Palmisano, G.; Pina, C.D.; Rossi, M.; Pagliaro, M. One-pot electrocatalytic oxidation of glycerol to DHA. Tetrahedron Lett., 2006, 47, 6993-6995.

[93] Pyle, D.J.; Garcia, R.A.; Wen, Z.Y. Producing docosahexaenoic acid (DHA)-rich algae from biodiesel-derived crude glycerol: effects of impurities on DHA production and algal biomass composition. J. Agric. Food Chem., 2008, 56, 3933-3939.

[94] Davis, W.R.; Tomsho, J.; Nikam, S.; Cook, E.M.; Somand, D. Peliska, J.A. Inhibition of HIV-1 reverse transcriptase-catalyzed DNA strand transfer reactions by 4-chlorophenylhydrazone of mesoxalic acid. Biochemistry, 2000, 39, 14279-14291.

[95] Kimura, H.; Tsuto, K. Catalytic synthesis of DL-serine and glycine from glycerol. J. Am. Oil Chem. Soc., 1993, 70(10), 1027-1030.

[96] Kim, Y.C.; Park, N.C.; Shin, J.S.; Lee, S.R.; Lee, Y.J.; Moon, D.J. Partial oxidation of ethylene to ethylene oxide over nanosized $\mathrm{Ag} / \alpha-\mathrm{Al}_{2} \mathrm{O}_{3}$ catalysts. Catal. Today, 2003, 87, 153-162.

[97] Bühler, W.; Dinjus, E.; Ederer, H.J.; Kruse, A.; Mas, C. Ionic reactions and pyrolysis of glycerol as competing reaction pathways in near- and supercritical water. J. Supercrit. Fluid, 2002, 22, 3753 .

[98] Hirai, T.; Ikenaga, N.O.; Miyake, T.; Suzuki, T. Production of hydrogen by steam reforming of glycerin on ruthenium catalyst. Energy Fuel, 2005, 19, 1761-1762.

[99] Soares, R.R.; Simonetti, D.A.; Dumesic, J.A. Glycerol as a source for fuels and chemicals by low-temperature catalytic processing. Angew Chem. Int. Ed., 2006, 45, 3982-3985.

[100] Baumann, H.; Bühler, M.; Fochem, H.; Hirsinger, F.; Zoebelein, H.; Falbe, J. Natural fats and oils - renewable raw materials for the chemical industry. Angew. Chem. Int. Ed. Engl., 1988, 27(1), 4162 .

[101] Melero, J.A.; Grieken, R.V.; Morales, G.; Paniagua, M. Acidic mesoporous silica for the acetylation of glycerol: synthesis of bioadditives to petrol fuel. Energy Fuel, 2007, 21, 1782-1791. 
[102] Clacens, J.M.; Pouilloux, Y.; Barrault, J. Selective etherification of glycerol to polyglycerols over impregnated basic MCM-41 type mesoporous catalysts. Appl. Catal. A-Gen, 2002, 227, 181-190.

[103] Kunieda, H.; Akahane, A.; Feng, J.; Ishitobi, M. Phase behavior of polyglycerol didodecanoates in water. J. Colloid Interf. Sci., 2002, 245, 365-370.

[104] Oudhoff, K.A.; VanDamme, F.A.; Mes, E.P.C.; Schoenmakers, P.J.; Kok, W.T. Characterization of glycerin-based polyols by capillary electrophoresis. J. Chromatogr. A, 2004, 1046, 263-269.

[105] Vieville, C.; Yoo, J.W.; Pelet, S.; Mouloungui, Z. Synthesis of glycerol carbonate by direct carbonatation of glycerol in supercritical $\mathrm{CO}_{2}$ in the presence of zeolites and ion exchange resins. Catal. Lett., 1998, 56, 245-247.

[106] Dibenedetto, A.; Pastore, C.; Aresta, M. Direct carboxylation of alcohols to organic carbonates: comparison of the group 5 element alkoxides catalytic activity an insight into the reaction mechanism and its key steps. Catal. Today, 2006, 115, 88-94.

[107] Aresta, M.; Dibenedetto, A.; Nocito, F.; Pastore, C. A study on the carboxylation of glycerol to glycerol carbonate with carbon dioxide: the role of the catalyst, solvent and reaction conditions. $J$. Mol. Catal. A-Chem., 2006, 257, 149-153.

[108] Plasman, V.; Caulier, T.; Boulos, N. Polyglycerol esters demonstrate superior antifogging properties for films. Plastics Additives Compd., 2005, 7(2), 30-33.

[109] Lee, S.H.; Park, D.R.; Kim, H.; Lee, J.; Jung, J.C.; Woo, S.Y., et al. Direct preparation of dichloropropanol (DCP) from glycerol using heteropolyacid (HPA) catalysts: a catalyst screen study. Catal. Commun., 2008, 9, 1920-1923.

[110] Volpato, G.; Rodrigues, R.C.; Heck, J.X.; Ayub, M.A.Z. Production of organic solvent tolerant lipase by staphylococcus caseolyticus EX17 using raw glycerol as substrate. J. Chem. Technol. Biot., 2008, 83, 821-828.

[111] Zhou, C.H.; Beltramini, J.N.; Fan, Y.X.; Lu, G.Q. Chemoselective catalytic conversion of glycerol as a biorenewable source to valuable commodity chemicals. Chem. Soc. Rev., 2008, 37, 527549 .

(C) Krishnan et al.; Licensee Bentham Open.

This is an open access article licensed under the terms of the Creative Commons Attribution Non-Commercial License (http://creativecommons.org/licenses/by$\mathrm{nc} / 3.0 /$ ) which permits unrestricted, non-commercial use, distribution and reproduction in any medium, provided the work is properly cited. 